\title{
Expression of estrogen receptors in the hypothalamo-pituitary-ovarian axis in middle-aged rats after re-instatement of estrus cyclicity
}

\author{
M. Böttner · S. Leonhardt $\cdot$ W. Wuttke $\cdot$ \\ T. Wedel $\cdot$ H. Jarry
}

Received: 3 March 2009/Accepted: 27 April 2009/Published online: 7 May 2009

(C) Springer Science+Business Media B.V. 2009

\begin{abstract}
During reproductive aging female rats enter an anovulatory state of persistent estrus (PE). In an animal model of re-instatement of estrus cyclicity in middle-aged PE rats we injected the animals with progesterone ( $0.5 \mathrm{mg}$ progesterone/ $\mathrm{kg}$ body weight) at 12:00 for 4 days whereas control animals received corn oil injections. After the last injection animals were analyzed at 13:00 and 17:00. Young regular cycling rats served as positive controls and were assessed at 13:00 and 17:00 on proestrus. Progesterone treatment of middle-aged $\mathrm{PE}$ rats led to occurrence of luteinizing hormone (LH), follicle stimulating hormone (FSH), and prolactin surges in a subset of animals that were denoted as responders. Responding middle-aged rats displayed a reduction of ER- $\beta$ mRNA in the preoptic area which was similar to the effect in young rats. Within the mediobasal hypothalamus, only young rats showed a decline of ER- $\alpha$ mRNA expression. A decrease of ER- $\alpha$ mRNA levels in the pituitary was observed in progesteroneresponsive rats and in young animals. ER- $\beta$ mRNA expression was reduced in young regular cycling rats. ER- $\beta$ mRNA levels in the ovary were reduced
\end{abstract}

M. Böttner $(\bowtie) \cdot T$. Wedel

Department of Anatomy, University of Kiel, Otto-Hahn-Platz 8, 24118 Kiel, Germany

e-mail: m.boettner@anat.uni-kiel.de

S. Leonhardt $\cdot$ W. Wuttke $\cdot$ H. Jarry

Department of Endocrinology, University of Göttingen,

Gottingen, Germany following progesterone treatment in PE rats and in young rats. Taken together our data show that cyclic administration of progesterone reinstates ovulatory cycles in intact aging females which have already lost their ability to display spontaneous cyclicity. This treatment leads to the occurrence of preovulatory LH, FSH and prolactin surges which are accompanied by differential modulation of ERs in the hypothalamus, the pituitary and the ovary.

Keywords Persistent estrus - Progesterone · Estrogen receptor $\cdot \mathrm{LH} \cdot$ Preoptic area .

Pituitary

\section{Introduction}

Reproductive aging in female rats is characterized by attenuation and delayed onset of the proestrus $\mathrm{LH}$ surges. These changes occur by the time the animals reach middle-age, i.e. at the age of 9-10 months (Cooper et al. 1980; Lu et al. 1985). During this period animals change from a pattern of regular estrus cycles to irregular cycles with an extended estrus phase (Nass et al. 1984). As rats age further, they enter an anovulatory state of persistent estrus (PE). The acyclic PE state is characterized by a lack of the preovulatory luteinizeing hormone (LH) surge, chronically elevated estradiol levels, and diminished progesterone secretion (Huang et al. 1978; Lu et al. 
1979). Whereas the loss of positive feedback of estradiol on LH secretion in PE rats is well established the implications of reduced progesterone levels are less clear.

A surge of prolactin occurs in female rats during proestrus in response to elevated steroid levels. Prolactin has primary or modulatory roles in the reproductive cycles of female mammals, and progesterone has been implicated in the feedback regulation of prolactin (Bole-Feysot et al. 1998; Freeman et al. 2000; Horseman et al. 1997). The proestrus surge of prolactin in the rat plays a major role in maintaining the function of the corpus luteum after ovulation (Smith et al. 1975). During most of the estrus cycle the secretion of $\mathrm{LH}$ and follicle-stimulating hormone (FSH) is maintained at a relatively low level by the negative feedback of estrogen and progesterone on the hypothalamic-pituitary-ovarian system (Fink 1988). In contrast, the preovulaory gonadotropin surge results from a positive feedback cascade. Initially, estradiol secreted by the ovaries triggers a surge of gonadotropin releasing hormone $(\mathrm{GnRH})$ and an increase in pituitary responsiveness to $\mathrm{GnRH}$. In the rat, neurons that synthesize and secrete $\mathrm{GnRH}$ are mainly located in the preoptic area (POA) whereas axons terminate in the mediobasal hypothalamus/ median eminence area (MBH). The negative feedback control of the GnRH system could be accomplished by sex hormones acting on either cognate receptors expressed in $\mathrm{GnRH}$ neurons or on gonadal-steroid responsive systems upstream of GnRH. Thus, the regulation of estrogen receptors by sex steroids plays an important role in reproductive functions.

Within the ovary, estradiol is an essential hormone for ovulation. It has been demonstrated that rat granulosa cells both synthesize and respond to estrogen (Hsueh et al. 1984). ER- $\beta$ is the predominant ER form expressed in the granulosa cells of growing and mature follicles in the rodent ovary (Fitzpatrick et al. 1999; Sar and Welsch 1999) and ER- $\beta$ knock out mice fail to exhibit efficient ovulation even when treated with exogenous gonadotropins (Couse and Korach 1999).

Progesterone is intrinsic to the maintenance of ovulatory cyclicity through its positive and negative actions on the hypothalamo-pituitary unit (Fink 1988; Kalra 1993; Levine 1997). The acute action of progesterone on proestrus is to cause a augmentation of the LH and FSH release action of GnRH (Krey and
Kamel 1990; Lagace et al. 1980; Turgeon and Waring 1990). Furthermore, expression of progesterone receptor (PR) has been described in the POA (Helena et al. 2006) and ovarian granulosa cells (Peluso 2004) indicating that progesterone might also exert biological functions on the level of the hypothalamus and the ovary.

The current study was designed to investigate the effect of progesterone in re-initiating estrus cyclicity in gonadally intact PE rats. We assessed responsiveness of the animals by measuring serum levels of $\mathrm{LH}$, FSH, prolactin and estradiol on proestrus at 13:00 and 17:00. Young regular cycling rats served as positive controls. Secondly, we measured mRNA expression of ER- $\alpha$ and ER- $\beta$ in the POA, MBH, pituitary, and ovary of these animals.

\section{Materials and methods}

Animals

The experimental procedures complied with the German animal welfare legislation. Young adult (3 months) and middle-aged (11-12 months) female Sprague Dawley rats (Winkelmann, Borchen, Germany) were used in this study. Animals were housed under standardized conditions (lights on from 06:00 to $18: 00,24^{\circ} \mathrm{C}$ room temperature, relative humidity of 30-70\%). Regular laboratory diet (Sniff, Soest, Germany) and water were available ad libitum. All animals were monitored for estrous cyclicity by vaginal smears. Beginning at the age of 8 months, estrus cycles of the middle-aged rats were controlled. 20 days after onset of persistent estrus, animals were injected subcutaneously with $0.5 \mathrm{mg}$ progesterone $/ \mathrm{kg}$ body weight dissolved in corn oil at 12:00 h while control animals received injections with corn oil. Monitoring of vaginal cytology was continued. Animals were again injected with progesterone on the two following proestrus days at 12:00. At 13:00, control animals and animals treated with progesterone were killed by decapitation. At 17:00, animals that received corn oil injections and progesteronetreated animals were sacrificed. Young animals that served as controls for the middle-aged group were monitored for three consecutive 4 day cycles. On proestrus day, animals were decapitated under $\mathrm{CO}_{2}$ anesthesia at 13:00 and at 17:00. 
Based on the LH levels, progesterone $(\mathrm{P})$ treated animals killed at 17:00 were grouped in those rats responding to steroid application with LH concentrations less than $5 \mathrm{ng} / \mathrm{ml}$ and animals which responded with a distinct $\mathrm{LH}$ peak, i.e. $\mathrm{LH}$ levels $>5 \mathrm{ng} / \mathrm{ml}$. The final assignment of animals to the experimental groups was (see also figures and respective legends): 13:00 -P (without $\mathrm{P}$ application at noon, 16 rats), 13:00 $+\mathrm{P}$ (injected with $\mathrm{P}$ at noon, 16 rats) 17:00 $-\mathrm{P}$ (rats without $\mathrm{P}$ application at noon $n=16$ ), $+\mathrm{P} / \mathrm{LH}<5$ (rats injected with progesterone at noon, responding with LH levels less than $5 \mathrm{ng} / \mathrm{ml}$ at 17:00 20 rats); $+\mathrm{P} / \mathrm{LH}>5$ (rats injected with progesterone at noon, responding with $\mathrm{LH}$ levels more than $5 \mathrm{ng} / \mathrm{ml}$ at 17:00 16 rats), Y13:00 and Y17:00: Young proestrus rats killed at 13:00 (16 rats) or 17:00 h (16 rats).

Hormone analysis

For determination of serum hormone levels by radioimmunoassay (RIA), blood was collected from the trunk. The blood samples were centrifuged $(3000 \mathrm{~g}, 20 \mathrm{~min})$ and the serum was stored at $-20^{\circ} \mathrm{C}$ for further analysis. LH, FSH, and prolactin were measured by a specific RIA supplied by the National Hormone and Pituitary Program of the NIH as described previously (Roth et al. 2001).

\section{Tissue preparation}

Following decapitation, the brain was removed from the skull and frozen immediately on dry ice. Pituitaries and ovaries were snap frozen in liquid nitrogen. All samples were stored at $-70^{\circ} \mathrm{C}$ until further processing. Brains were sliced into serial frontal sections $(600 \mu \mathrm{m}$ in depth) on a cryostat. Micropunches of the POA were taken from frozen slices with a 1-mm-diameter stainless needle according to the method of Palkovits (1973). The stereotactic coordinates were: A8.2, V7.5, L1.5. The MBH was cut out from the brain with a scalpel. The borders of the tissue pieces were the optic chiasm, the hypothalamic grooves and the mammillary bodies with a cut depth of $2 \mathrm{~mm}$.

RNA extraction and reverse transcription

Extraction of total RNA from pituitaries and micropunches was performed using a RNeasy mini kit
(Quiagen) according to the manufacturer's guidelines. Reverse transcription was carried out in a total volume of $20 \mu \mathrm{l}$ containing $1 \times$ reaction buffer (50 mM Tris- $\mathrm{HCl}, 75 \mathrm{mM} \mathrm{KCl}, 3 \mathrm{mM} \mathrm{MgCl}_{2}$, $50 \mathrm{mM}$ DTT), $100 \mathrm{ng}$ random hexamer primer, 0,5 mM dNTPs, 200 U M-MMLV Reverse Transciptase RNase H- (Promega), 4 U RNasin (Promega) 1-10 $\mu \mathrm{l}$ RNA and $1 \mu \mathrm{l}$ mutant RNA. Samples were incubated for $10 \mathrm{~min}$ at $22^{\circ} \mathrm{C}$ to allow primer annealing, reverse transcription took place at $42^{\circ} \mathrm{C}$ for $50 \mathrm{~min}$, finally RNA-cDNA hybrids were denatured for $10 \mathrm{~min}$ at $95^{\circ} \mathrm{C}$.

\section{Competitive RT-PCR}

For generation of mutant RNA templates, composite primers were designed for each probe. An RT-PCR reaction was carried out with composite primer plus the respective sense or antisense primer and the resulting PCR products were cloned using the TOPO TA cloning kit (Invitrogen, Groningen, The Netherlands). After sequencing, the mutant RNA was reverse transcribed with the Reverse Transcription System purchased from Promega (Mannheim, Germany). PCR was conducted using Supermix (GibcoBRL, Karlsruhe, Germany). Prior to RT reaction various amounts (10-100 fg) of mutant RNA were added to all reaction vials. The concentration of this cRNA was evaluated for each investigated gene by pilot titration experiments. For PCR reaction, 2-4 $\mu \mathrm{l}$ cDNA and $25 \mathrm{pM}$ primer were added to the Supermix solution. PCR procedure was performed in a Biometra automated thermocycler $\left(1 \mathrm{~min} 94^{\circ} \mathrm{C}, 1 \mathrm{~min}\right.$ $60^{\circ} \mathrm{C}, 2 \mathrm{~min} 72^{\circ} \mathrm{C}$ ). The program was run from 23 to 29 cycles. To destroy secondary structures, the PCR was continued with 5 cycles of $1 \mathrm{~min}$ at $78^{\circ} \mathrm{C}, 1 \mathrm{~min}$ at $60^{\circ} \mathrm{C}$ and $2 \mathrm{~min}$ at $72^{\circ} \mathrm{C}$. Primers for ER- $\alpha$ were: Sense primer: $5^{\prime}$-GGCGGATCCGACCAGATGTCAGTGCCT-3', antisense primer: 5'-GGCGTCGACAGATGCTCCATGCCTTTGTTAC- $3^{\prime}$; ER- $\beta$ sense primer: $5^{\prime}$-GCATCTGGGTATCATTACGG-3' ${ }^{\prime}$, antisense primer: 5'-GCCAGGAGCATGTCAAAGAT$3^{\prime}$.Ten microliters of the amplified PCR products were size-fractionated by electrophoresis in a $1.5 \%$ agarose gel in TBE buffer and stained with ethidium bromide. Bands were visualized at $254 \mathrm{~nm}$ and photographed with a Kodak DC 120 camera. Dendsitometric PCR signals were evaluated with the Kodak DC 1D program (Eastman Kodak Co., NY., USA). 
The arbitrary unit of each native DNA band was related to the corresponding mutant DNA value.

\section{Statistical evaluation}

All data are expressed as mean + SEM. Results obtained from the two groups of young animals were analysed via $t$-test. The effects of progesterone treatment of middle-aged rats were evaluated via one-way ANOVA and post-hoc analysis was carried out using Dunnett's test (Prism software, GraphPad, La Jolla, CA). All differences were considered significant at $P<0.05$.

\section{Results}

To determine the effectiveness of progesterone in reinstating estrus cyclicity, we first assessed serum $\mathrm{LH}, \mathrm{FSH}$, and prolactin levels in middle-aged, gonadally intact PE rats as well as in young regular cycling rats (Fig. 1). For this purpose, we examined (a) the effect of treatment at 13:00 and 17:00 and (b) the effect of time of day in progesterone-treated animals. Young regular cycling rats served as positive controls and were analyzed at 13:00 and 17:00.

Middle-aged rats studied at 13:00 showed low levels of LH that were not affected by progesterone treatment (Fig. 1a). Middle-aged rats treated with progesterone and analyzed at 17:00 exhibited a differential response. Twenty animals showed no LH peak and had serum LH levels below $5 \mathrm{ng} / \mathrm{ml}$ (mean $0.53 \mathrm{ng} / \mathrm{ml}$ ) and were therefore referred to as non-responders. In contrast, 16 rats exhibited $\mathrm{LH}$ concentrations above $5 \mathrm{ng} / \mathrm{ml}$ (mean: $15.3 \mathrm{ng} / \mathrm{ml}$ ) and were denoted as responders. Young rats killed at 17:00 showed significantly elevated LH levels compared to animals harvested at 13:00. Similar results were obtained regarding serum FSH levels (Fig. 2b). Middle-aged responding rats showed at 17:00 a significant increase in FSH concentrations compared to untreated rats or to progesterone-treated animals analyzed at 13:00 whereas non-responding rats exhibited only basal FSH levels. Progesterone treatment resulted in no change in FSH levels at 13:00. Young control animals exhibited a significant increase in FSH concentrations at 17:00 compared
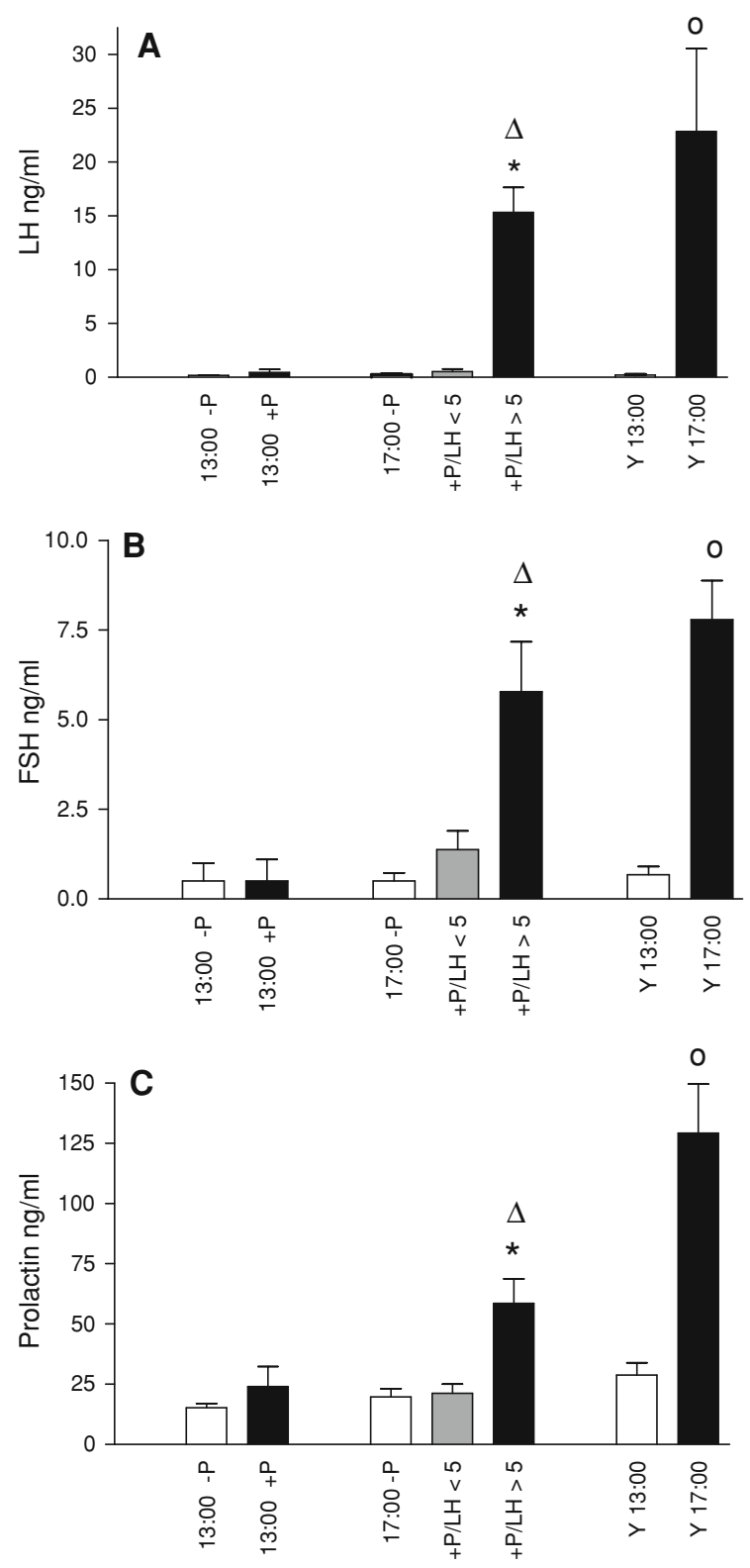

Fig. 1 Serum levels of LH, FSH, and prolactin. a shows serum levels of $\mathrm{LH}, \mathbf{b}$ of $\mathrm{FSH}$, and $\mathbf{c}$ of prolactin. In this and the following figures the abbreviations are: 13:00 -P and 17:00 -P: middle-aged rats without progesterone application at noon; 13:00 $+\mathrm{P}, 17: 00+\mathrm{P}$ : middle-aged rats with progesterone application at noon; $17+\mathrm{P} / \mathrm{LH}<5$, rats injected with progesterone at noon, responding with $\mathrm{LH}$ levels less than $5 \mathrm{ng} / \mathrm{ml}$ at 17:00; $+\mathrm{P} / \mathrm{LH}>5$, rats injected with progesterone at noon, responding with LH levels more than $5 \mathrm{ng} / \mathrm{ml}$ at 17:00; Y13:00 and Y17:00: Young proestrus rats killed at 13:00 or 17:00 h. Data are shown as mean \pm SEM. $*=P<0.05$ versus $-\mathrm{P}, \Delta=P<0.05$ vs. $13: 00+\mathrm{P}, \mathrm{o}=P<0.05$ versus Y13:00 


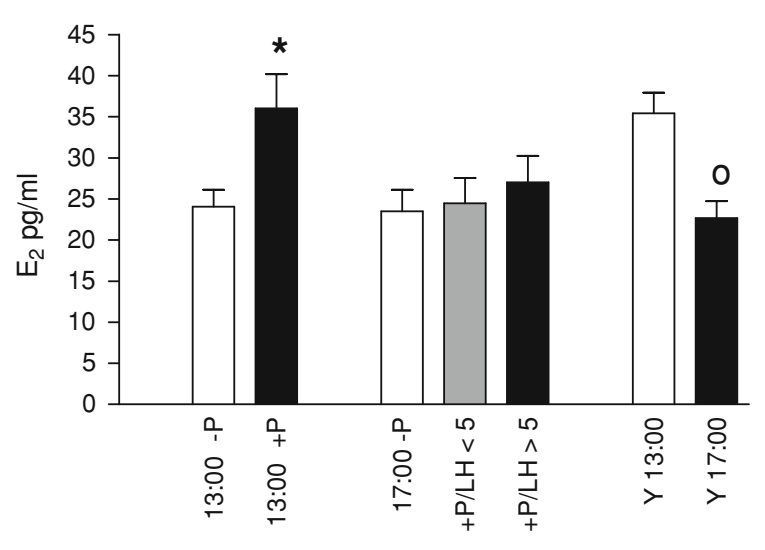

Fig. 2 Serum levels of estradiol. Data are shown as mean \pm SEM. $*=P<0.05$ versus $-\mathrm{P}, \mathrm{o}=P<0.05$ versus $\mathrm{Y} 13: 00$

to 13:00. Prolactin levels showed a similar secretion profile as observed for the gonadotropins (Fig. 1c). Middle-aged rats that responded to progesteronetreatment showed a significant elevation of prolactin levels at 17:00 compared to untreated controls or to progesterone-treated rats killed at 13:00. No effect of treatment was observed at 13:00. Young rats killed at 17:00 had significantly higher prolactin serum concentrations compared to age-matched animals killed at 13:00.

Middle-aged, progesterone-treated rats that were killed at 13:00 showed an significant increase in serum estradiol levels compared to untreated rats whereas no effect of hormone treatment was observed in the 17:00 group of animals (Fig. 2). Young regular cycling rats that served as positive controls showed a

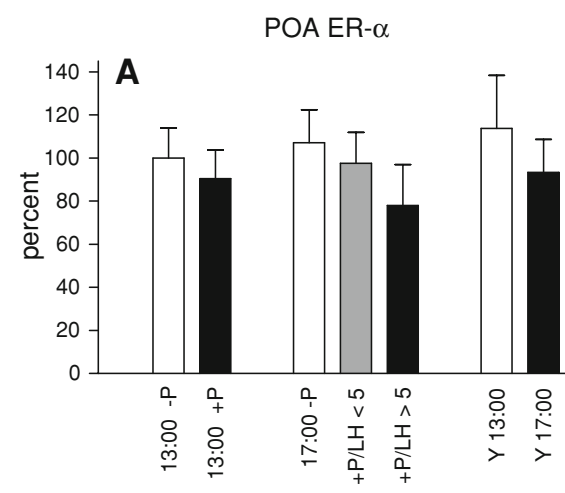

Fig. 3 ER mRNA expression in the POA. a shows the expression profile of ER- $\alpha$, b depicts mRNA levels for ER- $\beta$. In this and the following figures mRNA expression of middleaged rats analyzed at 13:00 without progesterone treatment was decrease in estradiol concentrations at 17.00 compared to 13:00.

We next investigated the mRNA expression for $\mathrm{ER}-\alpha$ and $\mathrm{ER}-\beta$ in various tissues involved in regulation of the estrus cycle. mRNA levels for the ERs in the POA following progesterone treatment are depicted in Fig. 3. ER- $\alpha$ mRNA expression was not affected by hormone treatment, age or time (Fig. 3a). Regarding ER- $\beta$ we observed significant down-regulation in middle-aged responding rats compared to untreated controls or compared to animals assessed at 13:00 (Fig 3b). Accordingly, young animals showed a decrease in ER- $\beta$ mRNA expression at 17:00 compared to 13:00.

Figure 4 depicts mRNA levels for ERs in the hypothalamic area where GnRH axon terminals reside. In young regular cycling rats ER- $\alpha$ mRNA expression in the $\mathrm{MBH}$ was significantly downregulated at 17:00 compared to 13:00 (Fig. 4a). This effect was abolished in PE rats irrespective of progesterone treatment. ER- $\beta$ mRNA expression in the MBH was not affected by treatment, time or age (Fig. 4b).

Furthermore, we assessed mRNA expression of both ERs in the anterior pituitary (Fig. 5). Following progesterone treatment ER- $\alpha$ mRNA levels in middle-aged animals increased significantly at 13:00 compared to untreated controls (Fig. 5a). Progesterone-treated animals analyzed at 17:00 showed a significant decrease in ER- $\alpha$ mRNA compared to hormone treated rats analyzed at 13:00. Consistently with these results young animals showed a decline in

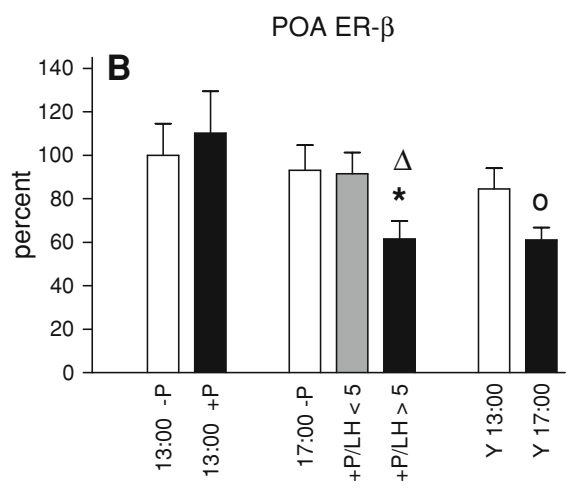

set as $100 \%$ and the mean values of the other treatment groups were expressed in relation to this group. Data are shown as mean \pm SEM. ${ }^{*}=P<0.05$ versus $-\mathrm{P}, \Delta=P<0.05$ vs. 13:00 $+\mathrm{P}, \mathrm{o}=P<0.05$ versus Y13:00 
Fig. 4 Levels of ER- $\alpha$ and ER- $\beta$ mRNA in the MBH. ER- $\alpha$ mRNA profiles are shown in (a), ER- $\beta$ mRNA expression is represented in (b). Data are shown as mean \pm SEM. $\mathrm{o}=P<0.05$ versus Y13:00

Fig. 5 mRNA expression profiles for ER- $\alpha$ and ER- $\beta$ in the anterior pituitary. ER$\alpha$ mRNA levels are depicted in (a), ER- $\beta$ mRNA

expression is shown in (b).

Data are shown as

mean \pm SEM.

$*=P<0.05$ versus $-\mathrm{P}$,

$\Delta=P<0.05$ vs.

13:00 $+\mathrm{P}, \mathrm{o}=P<0.05$

versus Y13:00

Fig. 6 ER mRNA

expression in the ovary.

Regulation of ER- $\alpha$ mRNA expression is shown in (a), ER- $\beta$ mRNA levels are represented in (b). Data are shown as mean \pm SEM.

$\Delta=P<0.05$ vs.

13:00 $+\mathrm{P}, \mathrm{o}=P<0.05$

vs. Y13:00
MBH ER- $\alpha$
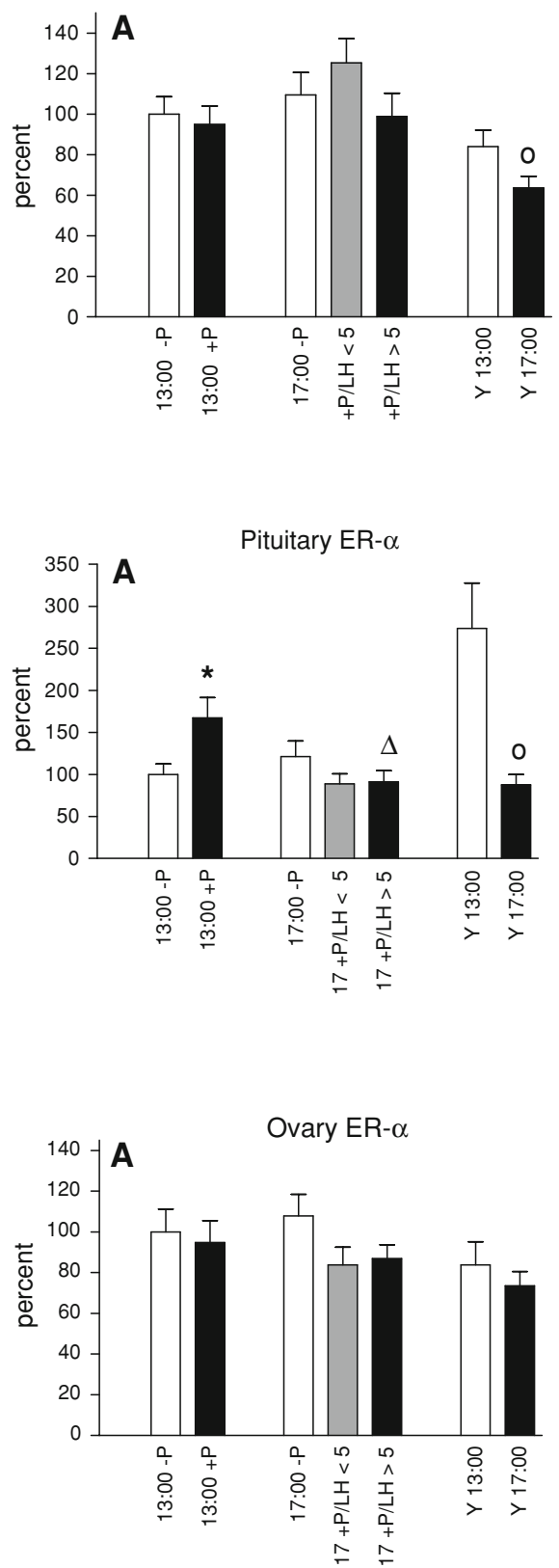

MBH ER- $\beta$

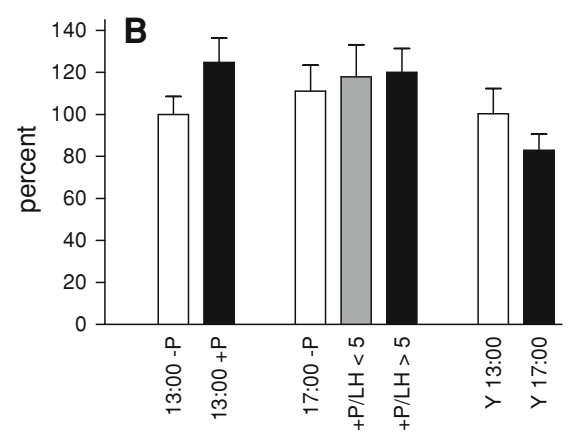

Pituitary ER- $\beta$
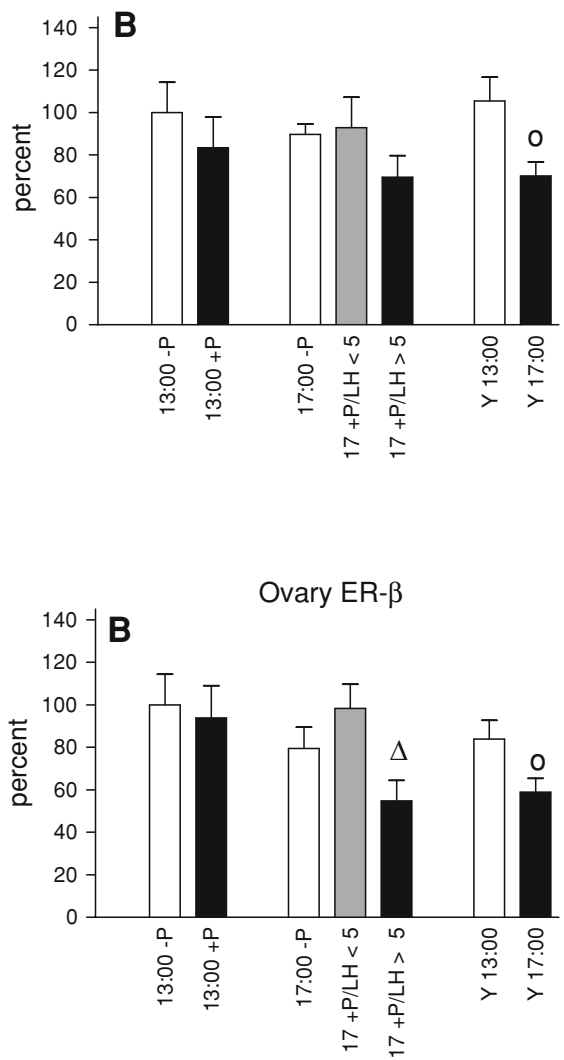

ER- $\alpha$ mRNA expression at 17:00 compared to 13:00. A similar expression profile was observed for $\operatorname{ER} \beta$ in young animals whereas middle-aged rats exhibited no changes in ER- $\beta$ mRNA expression (Fig. 5b).

We finally determined modulation of ERs in the ovary (Fig. 6). ER- $\alpha$ mRNA expression was not affected by treatment, time or age (Fig. 6a). In middle-aged responding rats ER- $\beta$ mRNA levels declined at 17:00 compared to progesterone-treated animals analyzed at 13:00 (Fig. 6b). A similar effect was observed in young rats assessed at 17:00 compared to animals harvested at 13:00.

\section{Discussion}

The aim of this study was to reinstate estrus cyclicity in middle-aged intact PE rats via application of 
progesterone and to assess the regulation of ER- $\alpha$ and ER- $\beta$ mRNA in the hypothalamo-pituitary-ovarian axis. To monitor responsiveness of our animals to hormone treatment we first assessed gonadotropin secretion. Remarkably, we observed differential modulation of LH and FSH secretion in middle-aged rats following progesterone application. Progesterone treatment led to the appearance of pronounced LH surges on the afternoon of proestrus in 16 out of 36 animals. These rats were therefore denoted as progesterone-responsive animals ( $\mathrm{LH}$ secretion $>5 \mathrm{ng} / \mathrm{ml}$ ). In contrast, 20 animals did not respond to progesterone treatment and were therefore referred to as nonresponders ( $\mathrm{LH}$ secretion $<5 \mathrm{ng} / \mathrm{ml}$ ). These data contrast data obtained by Tsai et al. (2004) who described that challenge with progesterone after estradiol priming of ovariectomized early PE rats reinstated LH surges in all rats that had become PE within 35 days. The discrepancy of these results might be explained by the fact that we investigated intact $\mathrm{PE}$ rats whereas the former study used ovariectomized, estradiol-primed animals. The rise in gonadotropin secretion observed in middle-aged PE rats on proestrus afternoon was preceded by an increase in plasma estradiol levels. Elevated estradiol levels are a prerequisite for the positive feedback action on gonadotropin secretion. Although it has been reported that in PE rats the gonadotropin surge response to the stimulation of estradiol is no longer effective (Day et al. 1988; Matt et al. 1987) our data reveal that in $44 \%$ of our animals application of progesterone in the presence of endogenous estradiol led to the re-ocurrence of gonadotropin peaks.

In addition, we observed an increase of prolactin on proestrus afternoon in young regular cycling rats and in progesterone-responsive middle aged rats. The preovulatory prolactin surge has been implicated in maintenance of corpus luteum functions and gene disruption of the mouse prolactin gene caused infertility in female mice (Horseman et al. 1997). Since lactotropes in the rat lack PR expression (Fox et al. 1990), it has been suggested that progesterone might exert indirect functions on lactotropes via actions on gonadotropes (Freeman et al. 2000). However, most studies investigating the site of progesterone action in modulating prolactin secretion have focused on the hypothalamus. For example, progesterone has been shown to affect prolactin secretion through its actions on the tuberoinfundibular dopamine system (Arbogast and Voogt 1994; Kohama and Bethea 1995). The significance of the hypothalamic action of progesterone in the regulation of prolactin secretion results in advancing or prolonging the estradiol-induced prolactin surge (Arbogast and Ben-Jonathan 1990; Caligaris et al. 1974; Yen and Pan 1998). In addition, POA neurons have been implicated in the control of prolactin secretion since lesion of this area blocks the prolactin peak induced by estradiol in ovariectomized rats (Pan and Gala 1985), and electric stimulation of the POA increases prolactin secretion in male rats (Colombo 1984).

During the reproductive cycle in the female progesterone modulates gonadotropin secretion at the level of the pituitary gland, as well as the hypothalamaus (Fink 1988; Kalra 1993). At the level of the pituitary gland, progesterone has been shown to regulate the magnitude and possibly the duration of the preovulatory gonadotropin surge (Banks and Freeman 1978; Krey and Kamel 1990; Turgeon and Waring 1990). In agreement with these results, Bellido et al. (2002) reported that LH and FSH secretion were reduced by application of the antiprogestin RU486 to isolated pituitaries. As RU486 reduces galanin (Sanchez-Criado et al. 2001) and activin (Szabo et al. 1998) stimulating effects on LH and FSH secretion, progesterone treatment appears to exert direct effects on the pituitary. Further evidence for this action is provided by the fact that upregulation of the PR by estrogen in the pituitary has been demonstrated by several reports (Bethea et al. 1996; Szabo et al. 2000; Turgeon et al. 1999). In rats, localization of the PR within the pituitary gland is restricted to gonadotropes (Fox et al. 1990; Turgeon et al. 1999). Thus, progesterone might increase the responsiveness of gonadotropes to GnRH or increase the production and secretion of LH and FSH.

The observed regulation of LH and FSH secretion might also be affected on the level of the hypothalamus. The progesterone-induced LH surge in the estrogen-primed rat is thought to be mediated through interneurons since GnRH neurons lack PRs (Fox et al. 1990). The inhibitory neurotransmitter gamma-aminobutyric acid (GABA) is converted from glutamate by the rate-limiting enzyme glutamic acid decarboylase (GAD). It has been demonstrated that progesterone treatment decreases GAD67 mRNA expression in the POA on proestrus at a time when LH peaks occur (Unda et al. 1995). Since furthermore the vast 
majority of cells containing PR immunoreactivity in the POA showed ER immunoreactivity (Warembourg et al. 1989) we next addressed the question how ER mRNA expression in the POA was regulated by progesterone. Our findings reveal that ER- $\beta$ mRNA expression in young rats and middle-aged responding rats was down-regulated on the afternoon of proestrus whereas ER- $\alpha$ mRNA levels remained unchanged. It has been demonstrated that disruption of the ER- $\alpha$ did not completely inhibit the induction of PR in the POA (Moffatt et al. 1998). This suggests that the induction of PR in ER $\alpha$-knockout mice may also be mediated by ER- $\beta$. Furthermore it has been demonstrated that GnRH neurons are immunopositive for ER- $\beta$ (Kallo et al. 2001) indicating that ER- $\beta$ might be responsible for mediating the estrogenic effect on $\mathrm{GnRH}$ secretion preceding the progesterone-induced LH peak. The observation that the dynamics in the expression pattern for ER- $\beta$ were not affected by age in the responding rats might provide a prerequisite for the re-establishment of estrus cyclicity.

Another cell population involved in regulating GnRH release are estrogen-receptive neurons located in the MBH (Caraty et al. 1998). Within this region we observed significant down regulation of ER- $\alpha$ at 17:00 in young animals. It has been described that gonadotropin-inhibitory neurons which are ER- $\alpha$ positive and respond to estrogens are located in the MBH of mammals (Kriegsfeld et al. 2006). Since in vivo gonadotropin inhibitory hormone administration rapidly inhibits $\mathrm{LH}$ secretion, a down-regulation of ER- $\alpha$ might lead to decreased sensitivity of these neurons to estrogens resulting in increased $\mathrm{LH}$ secretion. In addition, as many ER-expressing cells synthesize GABA (Herbison et al. 1993), decreased responsiveness to estradiol in the $\mathrm{MBH}$ of young animals may lead to increased LH secretion via a GABAergic mechanism. Since the differential expression of ER- $\alpha$ was restricted to young animals we assume that the age-related loss of ER- $\alpha$ mRNA decrease in the MBH may account for the decrease in LH secretion in middle-aged responding $(15.3 \mathrm{ng} / \mathrm{ml})$ compared to young $(22.8 \mathrm{ng} / \mathrm{ml})$ rats.

We next assessed expression of both ERs in the pituitary. Our data reveal that in young control animals ER- $\alpha$ mRNA expression was significantly decreased at 17:00 compared to 13:00. We also observed an effect of progesterone treatment and time in middle-aged rats. Progesterone application led to a transient increase in ER- $\alpha$ expression at 13:00 and a decrease at 17:00. It has been demonstrated that ER- $\alpha$ is the predominant form of ERs in the pituitary (Scully et al. 1997) and ER- $\alpha$ is expressed in high levels in lactotropes and gonadotropes (Mitchner et al. 1998). Therefore, the high levels of ER- $\alpha$ observed in young rats and middle-aged progesterone-treated animals at 13:00 might be partly responsible for the observed prolactin and LH surges. In addition, our data are in agreement with results obtained by Sanchez-Criado et al. (2005) who report that the proportion of ER- $\alpha$ positive cells co-localizing with LH vary with the estrus cycle being highest on proestrus. ER- $\beta$, in contrast, showed only significant down-regulation at 17:00 in young animals. Since disruption of the ER- $\beta$ gene has little effect on pituitary function in ERknockout models (Couse and Korach 1999) it is likely that this receptor is of minor importance regarding gonadotropin and prolactin secretion.

Since ovarian follicular development is primarily dependent on pituitary gonadotropins and estradiol, we next examined the differential expression of ERs in the ovary. We observed down regulation of ER- $\beta$ mRNA expression in young animals at and in middleaged responding rats at 17:00 whereas ER- $\alpha$ mRNA levels were not affected by progesterone treatment. The prevailing form of ER in the ovary is ER- $\beta$ (Byers et al. 1997) and ER- $\beta$ is expressed predominantly in granulosa cells (Fitzpatrick et al. 1999; O'Brien et al. 1999; Sar and Welsch 1999). Several reports document that high levels of $\mathrm{LH}$ decrease steady-state ER- $\beta$ mRNA levels in the granulosa cells of preovulatory follicles in vivo, as well as in granulosa cells cultured in vitro (Byers et al. 1997; Guo et al. 2001; O'Brien et al. 1999). Furthermore, the preovulatory gonadotropin surge has been shown to induce the transcription of the PR gene in granulosa cells (Clemens et al. 1998; Park-Sarge and Mayo 1994; Park-Sarge and Sarge 1995). Thus, it might be possible that LH decreases ER- $\beta$ mRNA expression via upregulation of PR.

Taken together our data show that cyclic administration of progesterone reinstates ovulatory cycles in intact aging females which have already lost their ability to display spontaneous cyclicity. This treatment leads to the occurrence of preovulatory LH and prolactin surges which are accompanied by differential modulation of ERs in the hypothalamus, the pituitary and the ovary. 


\section{References}

Arbogast LA, Ben-Jonathan N (1990) The preovulatory prolactin surge is prolonged by a progesterone-dependent dopaminergic mechanism. Endocrinology 126:246-252

Arbogast LA, Voogt JL (1994) Progesterone suppresses tyrosine hydroxylase messenger ribonucleic acid levels in the arcuate nucleus on proestrus. Endocrinology 135:343350. doi:10.1210/en.135.1.343

Banks JA, Freeman ME (1978) The temporal requirement of progesterone on proestrus for extinction of the estrogeninduced daily signal controlling luteinizing hormone release in the rat. Endocrinology 102:426-432

Bellido C, Aguilar R, Garrido-Gracia JC, Sanchez-Criado JE (2002) Effects of progesterone (P) and antiprogestin RU486 on LH and FSH release by incubated pituitaries from rats treated with the SERM LY11701 8- $\mathrm{HCl}$ and/or recombinant human FSH. J Endocrinol Invest 25:702-708

Bethea CL, Brown NA, Kohama SG (1996) Steroid regulation of estrogen and progestin receptor messenger ribonucleic acid in monkey hypothalamus and pituitary. Endocrinology 137:4372-4383. doi:10.1210/en.137.10.4372

Bole-Feysot C, Goffin V, Edery M, Binart N, Kelly PA (1998) Prolactin (PRL) and its receptor: actions, signal transduction pathways and phenotypes observed in PRL receptor knockout mice. Endocr Rev 19:225-268. doi: 10.1210/er.19.3.225

Byers M, Kuiper GG, Gustafsson JA, Park-Sarge OK (1997) Estrogen receptor-beta mRNA expression in rat ovary: down-regulation by gonadotropins. Mol Endocrinol 11:172-182. doi:10.1210/me.11.2.172

Caligaris L, Astrada JJ, Taleisnik S (1974) Oestrogen and progesterone influence on the release of prolactin in ovariectomized rats. J Endocrinol 60:205-215. doi: 10.1677/joe.0.0600205

Caraty A, Fabre-Nys C, Delaleu B, Locatelli A, Bruneau G, Karsch FJ, Herbison A (1998) Evidence that the mediobasal hypothalamus is the primary site of action of estradiol in inducing the preovulatory gonadotropin releasing hormone surge in the ewe. Endocrinology 139:1752-1760. doi:10.1210/en.139.4.1752

Clemens JW, Robker RL, Kraus WL, Katzenellenbogen BS, Richards JS (1998) Hormone induction of progesterone receptor (PR) messenger ribonucleic acid and activation of PR promoter regions in ovarian granulosa cells: evidence for a role of cyclic adenosine $3^{\prime}, 5^{\prime}$-monophosphate but not estradiol. Mol Endocrinol 12:1201-1214. doi: 10.1210/me.12.8.1201

Colombo JA (1984) Dissociation of prolactin and LH release responses after stimulation within the preoptic-suprachiasmatic region in male rats. Exp Clin Endocrinol 84:228234

Cooper RL, Conn PM, Walker RF (1980) Characterization of the LH surge in middle-aged female rats. Biol Reprod 23:611-615. doi:10.1095/biolreprod23.3.611

Couse JF, Korach KS (1999) Estrogen receptor null mice: what have we learned and where will they lead us? Endocr Rev 20:358-417. doi:10.1210/er.20.3.358

Day JR, Morales TH, Lu JK (1988) Male stimulation of luteinizing hormone surge, progesterone secretion and ovulation in spontaneously persistent-estrous, aging rats. Biol Reprod 38:1019-1026. doi:10.1095/biolreprod38.5. 1019

Fink G (1988) Oestrogen and progesterone interactions in the control of gonadotrophin and prolactin secretion. J Steroid Biochem 30:169-178. doi:10.1016/0022-4731(88) 90090-8

Fitzpatrick SL, Funkhouser JM, Sindoni DM, Stevis PE, Deecher DC, Bapat AR, Merchenthaler I, Frail DE (1999) Expression of estrogen receptor-beta protein in rodent ovary. Endocrinology 140:2581-2591. doi:10.1210/en.140.6. 2581

Fox SR, Harlan RE, Shivers BD, Pfaff DW (1990) Chemical characterization of neuroendocrine targets for progesterone in the female rat brain and pituitary. Neuroendocrinology 51:276-283. doi:10.1159/000125350

Freeman ME, Kanyicska B, Lerant A, Nagy G (2000) Prolactin: structure, function, and regulation of secretion. Physiol Rev 80:1523-1631

Guo C, Savage L, Sarge KD, Park-Sarge OK (2001) Gonadotropins decrease estrogen receptor-beta messenger ribonucleic acid stability in rat granulosa cells. Endocrinology 142:2230-2237. doi:10.1210/en.142.6.2230

Helena CV, de Oliveira Poletini M, Sanvitto GL, Hayashi S, Franci CR, Anselmo-Franci JA (2006) Changes in alphaestradiol receptor and progesterone receptor expression in the locus coeruleus and preoptic area throughout the rat estrous cycle. J Endocrinol 188:155-165. doi:10.1677/ joe. 1.06268

Herbison AE, Robinson JE, Skinner DC (1993) Distribution of estrogen receptor-immunoreactive cells in the preoptic area of the ewe: co-localization with glutamic acid decarboxylase but not luteinizing hormone-releasing hormone. Neuroendocrinology 57:751-759. doi:10.1159/ 000126433

Horseman ND, Zhao W, Montecino-Rodriguez E, Tanaka M, Nakashima K, Engle SJ, Smith F, Markoff E, Dorshkind K (1997) Defective mammopoiesis, but normal hematopoiesis, in mice with a targeted disruption of the prolactin gene. EMBO J 16:6926-6935. doi:10.1093/emboj/16.23. 6926

Hsueh AJ, Adashi EY, Jones PB, Welsh TH Jr (1984) Hormonal regulation of the differentiation of cultured ovarian granulosa cells. Endocr Rev 5:76-127. doi:10.1210/edrv$5-1-76$

Huang HH, Steger RW, Bruni JF, Meites J (1978) Patterns of sex steroid and gonadotropin secretion in aging female rats. Endocrinology 103:1855-1859

Kallo I, Butler JA, Barkovics-Kallo M, Goubillon ML, Coen CW (2001) Oestrogen receptor beta-immunoreactivity in gonadotropin releasing hormone-expressing neurones: regulation by oestrogen. J Neuroendocrinol 13:741-748. doi:10.1046/j.1365-2826.2001.00708.x

Kalra SP (1993) Mandatory neuropeptide-steroid signaling for the preovulatory luteinizing hormone-releasing hormone discharge. Endocr Rev 14:507-538

Kohama SG, Bethea CL (1995) Steroid regulation of tyrosine hydroxylase messenger ribonucleic acid in dopaminergic subpopulations of monkey hypothalamus. Endocrinology 136:1790-1800. doi:10.1210/en.136.4.1790 
Krey LC, Kamel F (1990) Progesterone modulation of gonadotropin secretion by dispersed rat pituitary cells in culture. I. Basal and gonadotropin-releasing hormonestimulated luteinizing hormone release. Mol Cell Endocrinol 68:85-94. doi:10.1016/0303-7207(90)90180-G

Kriegsfeld LJ, Mei DF, Bentley GE, Ubuka T, Mason AO, Inoue K, Ukena K, Tsutsui K, Silver R (2006) Identification and characterization of a gonadotropin-inhibitory system in the brains of mammals. Proc Natl Acad Sci USA 103:2410-2415. doi:10.1073/pnas.0511003103

Lagace L, Massicotte J, Labrie F (1980) Acute stimulatory effects of progesterone on luteinizing hormone and follicle-stimulating hormone release in rat anterior pituitary cells in culture. Endocrinology 106:684-689

Levine JE (1997) New concepts of the neuroendocrine regulation of gonadotropin surges in rats. Biol Reprod 56:293302. doi:10.1095/biolreprod56.2.293

Lu KH, Hopper BR, Vargo TM, Yen SS (1979) Chronological changes in sex steroid, gonadotropin and prolactin secretions in aging female rats displaying different reproductive states. Biol Reprod 21:193-203. doi:10.1095/biol reprod21.1.193

Lu JK, LaPolt PS, Nass TE, Matt DW, Judd HL (1985) Relation of circulating estradiol and progesterone to gonadotropin secretion and estrous cyclicity in aging female rats. Endocrinology 116:1953-1959

Matt DW, Coquelin A, Lu JK (1987) Neuroendocrine control of luteinizing hormone secretion and reproductive function in spontaneously persistent-estrous aging rats. Biol Reprod 37:1198-1206. doi:10.1095/biolreprod37.5.1198

Mitchner NA, Garlick C, Ben-Jonathan N (1998) Cellular distribution and gene regulation of estrogen receptors alpha and beta in the rat pituitary gland. Endocrinology 139:3976-3983. doi:10.1210/en.139.9.3976

Moffatt CA, Rissman EF, Shupnik MA, Blaustein JD (1998) Induction of progestin receptors by estradiol in the forebrain of estrogen receptor-alpha gene-disrupted mice. J Neurosci 18:9556-9563

Nass TE, LaPolt PS, Judd HL, Lu JK (1984) Alterations in ovarian steroid and gonadotrophin secretion preceding the cessation of regular oestrous cycles in ageing female rats. J Endocrinol 100:43-50. doi:10.1677/joe.0.1000043

O'Brien ML, Park K, In Y, Park-Sarge OK (1999) Characterization of estrogen receptor-beta (ERbeta) messenger ribonucleic acid and protein expression in rat granulosa cells. Endocrinology 140:4530-4541. doi:10.1210/en.140. 10.4530

Palkovits M (1973) Isolated removal of hypothalamic or other brain nuclei of the rat. Brain Res 59:449-450. doi: 10.1016/0006-8993(73)90290-4

Pan JT, Gala RR (1985) Central nervous system regions involved in the estrogen-induced afternoon prolactin surge. I. Lesion studies. Endocrinology 117:382-387

Park-Sarge OK, Mayo KE (1994) Regulation of the progesterone receptor gene by gonadotropins and cyclic adenosine $3^{\prime}, 5^{\prime}$-monophosphate in rat granulosa cells. Endocrinology 134:709-718. doi:10.1210/en.134.2.709

Park-Sarge OK, Sarge KD (1995) Cis-regulatory elements conferring cyclic $3^{\prime}, 5^{\prime}$-adenosine monophosphate responsiveness of the progesterone receptor gene in transfected rat granulosa cells. Endocrinology 136:5430-5437. doi: 10.1210/en.136.12.5430

Peluso JJ (2004) Rapid actions of progesterone on granulosa cells. Steroids 69:579-583. doi:10.1016/j.steroids.2004. 05.006

Roth C, Schricker M, Lakomek M, Strege A, Heiden I, Luft H, Munzel U, Wuttke W, Jarry H (2001) Autoregulation of the gonadotropin-releasing hormone $(\mathrm{GnRH})$ system during puberty: effects of antagonistic versus agonistic GnRH analogs in a female rat model. J Endocrinol 169: 361-371. doi:10.1677/joe.0.1690361

Sanchez-Criado JE, Bellido C, Aguilar R, Garrido-Gracia JC (2001) Antiprogestin RU486 blunts the stimulatory effect of galanin on LH secretion from rat pituitaries in vitro in an estrous cycle stage-dependent manner. Neurosci Lett 305:73-75. doi:10.1016/S0304-3940(01)01799-2

Sanchez-Criado JE, de Las Mulas JM, Bellido C, Aguilar R, Garrido-Gracia JC (2005) Gonadotrope oestrogen receptor-alpha and -beta and progesterone receptor immunoreactivity after ovariectomy and exposure to oestradiol benzoate, tamoxifen or raloxifene in the rat: correlation with LH secretion. J Endocrinol 184:59-68. doi:10.1677/ joe. 1.05748

Sar M, Welsch F (1999) Differential expression of estrogen receptor-beta and estrogen receptor-alpha in the rat ovary. Endocrinology 140:963-971. doi:10.1210/en.140.2.963

Scully KM, Gleiberman AS, Lindzey J, Lubahn DB, Korach KS, Rosenfeld MG (1997) Role of estrogen receptor-alpha in the anterior pituitary gland. Mol Endocrinol 11:674681. doi:10.1210/me.11.6.674

Smith MS, Freeman ME, Neill JD (1975) The control of progesterone secretion during the estrous cycle and early pseudopregnancy in the rat: prolactin, gonadotropin and steroid levels associated with rescue of the corpus luteum of pseudopregnancy. Endocrinology 96:219-226

Szabo M, Kilen SM, Saberi S, Ringstrom SJ, Schwartz NB (1998) Antiprogestins suppress basal and activin-stimulated follicle-stimulating hormone secretion in an estrogen-dependent manner. Endocrinology 139:2223-2228. doi:10.1210/en.139.5.2223

Szabo M, Kilen SM, Nho SJ, Schwartz NB (2000) Progesterone receptor $\mathrm{A}$ and $\mathrm{B}$ messenger ribonucleic acid levels in the anterior pituitary of rats are regulated by estrogen. Biol Reprod 62:95-102. doi:10.1095/biolreprod62.1.95

Tsai HW, LaPolt PS, Olcott AP, Lu JK (2004) Temporal changes occur in the neuroendocrine control of gonadotropin secretion in aging female rats: role of progesterone. Biol Reprod 71:845-852. doi:10.1095/biolreprod.104.02 9090

Turgeon JL, Waring DW (1990) Rapid augmentation by progesterone of agonist-stimulated luteinizing hormone secretion by cultured pituitary cells. Endocrinology 127:773-780

Turgeon JL, Van Patten SM, Shyamala G, Waring DW (1999) Steroid regulation of progesterone receptor expression in cultured rat gonadotropes. Endocrinology 140:2318-2325. doi:10.1210/en.140.5.2318

Unda R, Brann DW, Mahesh VB (1995) Progesterone suppression of glutamic acid decarboxylase (GAD67) mRNA levels in the preoptic area: correlation to the luteinizing 
hormone surge. Neuroendocrinology 62:562-570. doi: 10.1159/000127064

Warembourg M, Jolivet A, Milgrom E (1989) Immunohistochemical evidence of the presence of estrogen and progesterone receptors in the same neurons of the guinea pig hypothalamus and preoptic area. Brain Res 480:1-15. doi: 10.1016/0006-8993(89)91561-8
Yen SH, Pan JT (1998) Progesterone advances the diurnal rhythm of tuberoinfundibular dopaminergic neuronal activity and the prolactin surge in ovariectomized, estrogen-primed rats and in intact proestrous rats. Endocrinology 139:1602-1609. doi:10.1210/en.139.4.1602 